DOI

\title{
ИМПЛЕМЕНТАЦИЯ СТРАТЕГИИ ФИЗИЧЕСКОЙ И РЕАБИЛИТАЦИОННОЙ МЕДИЦИНЫ В МЕДИЦИНСКУЮ РЕАБИЛИТАЦИЮ УКРАИНЫ
}

\author{
А. А. Владимиров, Л. Я. Васильева-Линецкая \\ Национальная медицинская академия последипломного образования имени П. Л. Шупика \\ Харьковская медицинская академия последипломного образования
}

\section{IMPLEMENTATION OF PHYSICAL AND REHABILITATION MEDICINE STRATEGY IN THE UKRAINIAN MEDICAL REHABILITATION}

\author{
O. A. Vladymyrov, L. Ya.Vasyleva-Linetska ${ }^{1}$ \\ Shupyk National Medical Academy of Postgraduate Education \\ ${ }^{1}$ Kharkiv Medical Academy of Postgraduate Education
}

Введение. В сентябре 2015 года Украинское общество физической и реабилитационной медицины было принято в Европейскую секцию физической и реабилитационной медицины Европейского союза медицинских специалистов. Важной задачей сегодняшнего дня является введение в Украине специальности «Врач физической и реабилитационной медицины», что будет способствовать дальнейшей интеграции национальной медицины с европейской.

Результаты и их обсуждение. Физическая и реабилитационная медицина (ФРМ) - относительно новая специальность, созданная для внедрения концепции реабилитации под руководством одного врача, использующего комплексную мультидисциплинарную персонализированную стратегию. Врач ФРМ руководит медицинской реабилитацией в амбулаторных и стационарных специализированных отделениях, в санаторнокурортных учреждениях и спа-центрах. Он применяет не только традиционные консервативные методы лечения, в том числе медикаментозные, но и использует физикальную и бальнеотерапию, кинезотерапию, хиропрактику и мануальную терапию, эргодиагностику и эрготерапию. Врач
ФРМ может работать в качестве ведущего реабилитационной команды и эксперта в области ФРМ. Количество врачей ФРМ в странах Евросоюза различно и составляет, на 100 тыс. населения, в Австрии - 1,8, в Бельгии - 4,4, в Германии - 2,0, в Дании - 4,7, в Испании - 4,9, в Норвегии - 2,1, в Польше - 2,3, в Румынии - 3,1, в Чехии - 1,7, в Швейцарии - 1,9 и в Швеции - 3,6 врача.

Последипломная подготовка врача ФРМ в странах ЕС осуществляется в течение 5-6 лет, из них 24 месяца проводится обучение по общим обязательным программам (интернатура); 36-48 месяцев осуществляется специализированное образование (резидентура), программа которого не является унифицированной и имеет в разных странах свои особенности, однако включает все общепринятые для данной специальности дисциплины.

Вывод. Стратегия развития ФРМ определяет ее место в современной медицине и способствует реализации высокого потенциала, накопленного специалистами многих стран мира, что определяет необходимость ее имплементации в медицинскую реабилитацию Украины. 